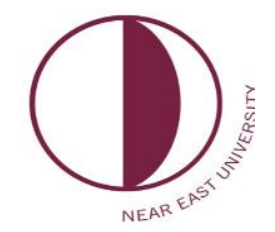

\title{
DETERMINATION OF THE LEVEL OF MEETING THE PROFESSIONAL EXPECTATIONS OF THE SCHOOL COUNSELORS AND PSYCHOLOGICAL COUNSELORS WORKING IN SCHOOLS, BY SCHOOL ADMINISTRATORS
}

\author{
Meltem Ceylan', Ahmet Şirin",* \\ ${ }^{1}$ Istanbul Sariyer Guidance and Research Center Assistant Director - Master Student at Department of \\ Education Management and Supervision, Istanbul Aydin University, Istanbul, Turkey, \\ meltemceylan34@gmail.com \\ ${ }^{2}$ Department of Psychological Counselling and Guidance, Marmara University, Istanbul, Turkey, \\ asirinn@gmail.com \\ Correspondence: meltemceylan34@gmail.com; Tel.: +0505 3475829
}

\begin{abstract}
In such an age in which social change is speedy, it is needed that individuals have both informed, equipped. Also their problem solving skills should be improved. However realization of themselves with the individual problems that people are facing is not a subject of teaching. These problems are action field of psychological and school counselor. Despite of our country's 50 years past, PCG (Psychological Counseling and Guiding) is still seen as a new field of service in our system of education. In this field of service, role that is expected from the workers hasn't reached a consensus. Not being identified the role of psychological and school counselors in schools exactly, with regard to the region in which school counselors work, type of school to the school principal ends up with a change in the expectations. In addition this situation turns out to be conflict in school. In this research, the absence of information, the determination of different manners and implementations and giving solution offers for the problem fields are aimed.
\end{abstract}

Keywords: psychological and school counsellor, occupational expectations, school principal, counselling

\section{Introduction}

Education is a forming process which aims to make terminal changes in individual's life intentionally through his/her living (Kaya 2007). School is an organization in which terminal information, skills and behaviours are brought in through exclusive, general aims and essential principles of the system of education (Aytac, 2000). School counselling is saving Schedule which helps individual to have experience to solve the problems and to be a free and responsible member of society in which he/she lives in (Glanz, 1974).

The aim of the school counselling -by providing rich and accurate information about himself and his environment to individual as much as possible-is to help individual to absorb this information, represent in behaviours and be the one who is able to solve the problem. Because of this function of it, the counselling is inseparable part of the system of education 
(Turkoglu, 1997). The other concept that we need to introduce is psychological counselling. Although concept of Psychological counselling and school counselling are different from each other, they are used together in literature. Psychological counselling is mutual interview between to people with the aim of solving a problem (Sirin, 2004). Psychological counselling constitutes only one section of the school counselling services.

\subsection{History of Psychological Counselling and Guiding}

It is seen that Roots of school counselling and psychological counselling are reaching to 1900's and that they started in America for the first time. Frank Parsan -who is an engineer- is known to have established the very first occupational office in 1908 to announce the job opportunities to the students which was started to try in 1895. Frank Parson whose aim was to hire -after accelerated education Schedule-many of the migrants who were searching for jobs in industrial zones can be accepted as the official founder of the counselling and 1908 can be also accepted as the year which is the official start of services of counselling.

With the coming out of future generation's being needed to be saved, the movement of school counselling was born. People who realize that the protection of mental and physical health of teenagers and children who was working as laborer and that these children should be provided education started to find a solution to these problems.

After the World War I (especially after Great Depression in 1930's), educators started to use psychological counselling term more frequently. With the effects of the World War II, the social changes in the U.S.A started to speed up, the rates of divorcing and crime increased and all these improvements made psychological help and mental healt to be cared much more significantly.

Increasing the need of psychological help resulted with being in need of educated people. The concept of "Mental health" took part in literature in these years. In 1950's counselling service took part in student personality service and the job definition (Gazioğlu ve.dğr. 2008: 26-28).

The counselling movement which started in America was born as occupational counselling movement at first. (Y1lmaz and Ure 2002). It can be said that respectively, firstly, occupational counselling, educational counselling and after those personal counselling and lastly, psychological counselling have improved.

It was observed that PCG in Europe was improving more slowly than America, that improvements increased after 1950's, and that occupational counselling was given importance rather than personal problems. It's known that studies of PDR are usually carried out by teachers with a little number of experts (Ay 2000).

While during the Middle Age of Europe people who are psychologically ill were chained as "cursed creature who's got devil inside", then they were shot, beaten, in Turk-Islam society people like them were showed affection, given special attention and examined (Tan 2000).

It's known that its name is not counselling and also that the studies to examine mental illness and problems were conducted by shamanist in Central Asia.

After acceptance of Islam the importance given to mental health and studies about it went on. Ibn-i Sina took care of mental health, melancholy and mental illnesses and made evaluations about the effects of mental health on physical health.

Seljuq Turks took special care of mental and physical illnesses. They got establish a lot of hospital examining mental health in. 
The importance given to mental health increased in Ottoman period and also social complexes -which was also social welfare center - were built in certain areas.

During republic years, John DAWEY who is educator-philosopher from the U.S.A, prepared a report by analyzing the Turkish education system. Following years, He establish village institutes and community centers by taking the general need of country into consideration. These foundations, played an effective role in raising individuals who has democratic personal structure which country needed.

It's seen that Turkish education system, which was influenced by European education system before, started to be influenced by the U.S.A with the improving relationships between Turkey and the U.S.A after World War II. (Ozoglu, 1982).

In our country, counselling started to take part in Gazi Education Institute as an independent lecture in Schedule during 1953-54 academic year for the first time. Counselling and Researching centers were opened in Istanbul and Izmir 1959 afterwards they were opened in our other cities.

During 1960's the department of Educational Sciences of Hacettepe University were established. Afterwards, "Psychological Counselling and Guidance" became an independent department in 1974 (Ozoglu, 2000). This department is the first department which was established under the name of "PDR" in Turkey.

Turkish Education board carried establishment and missions of counselling services in our moderate schools into practice in 24 schools in 1970. The department of Psychological Counselling and Guidance reorganized as "department" in license level with the regulations of in accordance with the higher education law 2547. In this period due to not being able to find staff in Ministry of National Education, psychological counselling and counselling guides started to work in schools only in 1985-86.

School counselling and guidance services have gone through several phases. While it was expected from counselling service to help choosing profession and work placement between the years of 1900 and 1921, the adaption and the educational success gained importance. "Through the end of 1960's the concepts of psychological counselling and guidance services came to exist for improving" (Terzi, 2005).

\section{Method}

\subsection{Method of Quantitative Research}

In this research, mixed method has been used. Data which has been collected by Qualitative and Quantitative has been analyzed separately and Qualitative Method has been used for the credibility of Quantitative Method a questionnaire developed for measuring the level of meeting the expectations of school counselors and psychological counselors working in schools was prepared and applied to the guidance counselors. The reason why the mixed method is chosen is the aim of the method diversity to contribute to the validity and reliability of the research.

The study group consisted of 42 female, 13 male, 55 guidance teachers working at all levels of official / private education in Sariyer district of Istanbul. The sample selection was done with random assignment and no prediction was made about the size of the sample. Firstly, the questionnaire, which was prepared to collect multi-concurrent data and to get rid of time and space constraints, has been turned into an application that can be answered by computer and 
phone via internet and data collection has been continued for the period determined by the researcher. In this context, theoretical sampling approach was used in addition to random assignment.

A 30-question questionnaire and a 10-question questionnaire were used as a result of the researcher's time in the field and the observations made in the natural environment..

During the study, the data collected from the questionnaires applied to the school counsellors were transferred to the computer using the Excel program. Data of the study analyzed via program of IBM SPSS 23.

In the study, because of the use of random sampling, there was no equality between the groups where the comparison was made, and since numerical data did not have normal distribution, non-parametric tests were used to obtain more accurate results in the analysis of the data. Non-parametric tests used in data analysis of this research; Mann-Whitney U test and Kruskal-Wallis Test.

\subsection{Method of Qualitative Research}

Interviewing form consisting of 10 questions was prepared to annihilate the finitiness of the survey which was used as assessment tool. Interviewees were conducted using extensive interview techniques from 15 respondents who volunteered among the respondents and in this point sample selection was made by random assignments. The percentage of teachers interviewed is that 11 of them $(\% 73,3)$ are female, 4 of them $(26,7)$ are male. Ten of these teachers work in public schools and five of them work in private schools.

In this research, the interview form which is used includes 10 questions in 5 different themes, including physical working conditions of the counselors, the attitude of the school principals to the guidance service, the attitude of the counselors towards their personal development, the attitude of the counselor in conflict situations, and the attitude of the counselor about the participation in the school decisions.

Content analysis was used to analyze the interviews with the counselors. Participants differ from each other in terms of the school level, the status of the school, age and seniority. In the analysis of the data obtained from the interviews, there is a list of codes that were generated before the interview, but in the later stages of the analysis new codes were added to the list and some of the old codes were changed. In this sense, data analysis was done on the computer in accordance with computer coding in a general structure, which is one of the coding methods of descriptive content analysis. MAXQDA program (version 18.2) was used during coding.

The common answers and expressions used by the participants are indicated in percentages according to the similarities with the answers determined by the researcher. Different, detailed or personalized answers are given by quotation.

\section{Results}

\subsection{Quantitative Research Results}

In this study, among the groups in which comparisons were to be made (in terms of the number of men and women), the equation could not be obtained due to the use of random sampling. Non-parametric tests were used to achieve healthier results. 
3.1.1. Differences in the Level of Meeting the Expectation of Female and Male Counselors by School Administrators

According to the results of the Mann-Whitney U test, there was no significant difference between the female teachers (Median $=127.5 \mathrm{n}=42$ ) and male (Median $=131, \mathrm{n}=13$ ) guidance counselors in terms of the level of their professional expectations met by the school administrators, $\mathrm{U}=239.5, \mathrm{z}=-0.66, \mathrm{p}=0.51, \mathrm{r}=0.09$

Table 1. Differences in the Level of Meeting the Expectations of Female and Male Counselors by School Administrators

\begin{tabular}{lccccccc}
\hline Points & Groups & $\mathbf{N}$ & $\begin{array}{c}\text { Mean } \\
\text { Rank }\end{array}$ & $\begin{array}{c}\text { Sum of } \\
\text { Ranks }\end{array}$ & Mann-Whitney U Test \\
& & & & & $\mathbf{U}$ & $\mathbf{Z}$ & $\begin{array}{c}\text { Asymp. } \\
\text { Sig }\end{array}$ \\
\hline \multirow{2}{*}{ Gender } & Female & 42 & 27,20 & 1142,50 & & &, 507 \\
& Male & 13 & 30,58 & 397,50 & & & \\
\hline
\end{tabular}

3.1.2. Level Differences of the Expectations of the Teachers by School Administrators According to the Total Service Times in the Profession

According to the results of Kruskal-Wallis Test, the year of service in the profession is 1-5 years $(n=15), 6-10$ years $(n=13), 11-15$ years $(n=11), 16-20$ years $(n=10)$, and 21 years above $(n=6)$, there is no significant difference in terms of the level of meeting the professional expectations of the guidance teachers by the school administrators, $X 2(4, n=55)=2.80, p=$ 0.59 .

Table 2. Level Differences of the Expectations of the Teachers by School Administrators According to the Total Service Periods

\begin{tabular}{|c|c|c|c|c|c|c|}
\hline \multirow{2}{*}{ Points } & \multirow{2}{*}{ Groups } & \multirow{2}{*}{$\mathbf{N}$} & \multirow{2}{*}{$\begin{array}{c}\text { Mean } \\
\text { Ran }\end{array}$} & \multicolumn{3}{|c|}{ Kruskal-Wallis Test } \\
\hline & & & & $\begin{array}{c}\text { Chi- } \\
\text { Square }\end{array}$ & dff & $\begin{array}{c}\text { Asymp. } \\
\text { Sig }\end{array}$ \\
\hline \multirow{8}{*}{$\begin{array}{c}\text { Years of } \\
\text { Occupational } \\
\text { Service }\end{array}$} & $1-5$ Year & 15 & 24,47 & & & \\
\hline & 6-10 Years & 13 & 26,96 & & & \\
\hline & $11-15$ & 11 & 34,77 & 2,79 & 4 & ,592 \\
\hline & Years & & & & & \\
\hline & $16-20$ & 10 & 28,05 & & & \\
\hline & Years & & & & & \\
\hline & $\begin{array}{l}21 \text { Years } \\
\text { and upper }\end{array}$ & 6 & 26,58 & & & \\
\hline & Total & 55 & & & & \\
\hline
\end{tabular}


3.1.3. Level Differences of the Expectations of the Vocational Expectations by School Administrators by Type of Institution in Which Counsellors Are Working

According to the results of the Mann-Whitney U test, it was found that there was no significant difference in the type of institution that the guidance counselors worked in (state or private) in terms of the level of meeting their professional expectations by the school administrators. (for state schools Median=129, n=37, özel okullar için Median=133, n=18), $\mathrm{U}=270.5, \mathrm{z}=-1.12, \mathrm{p}=0.26, \mathrm{r}=0.15$.

Table 3. Level Differences of the Expectations of the Vocational Expectations by School Administrators by Type of Institution in Which They Are Working

\begin{tabular}{|c|c|c|c|c|c|c|c|}
\hline \multirow{2}{*}{ Points } & \multirow{2}{*}{ Groups } & \multirow{2}{*}{$\mathbf{N}$} & \multirow{2}{*}{$\begin{array}{l}\text { Mean } \\
\text { Rank }\end{array}$} & \multirow{2}{*}{$\begin{array}{c}\text { Sum of } \\
\text { Ranks }\end{array}$} & \multicolumn{3}{|c|}{ Mann-Whitney U Test } \\
\hline & & & & & $\mathbf{U}$ & $\mathbf{Z}$ & $\begin{array}{c}\text { Asymp. } \\
\text { Sig }\end{array}$ \\
\hline \multirow{3}{*}{$\begin{array}{l}\text { Type of } \\
\text { Institution }\end{array}$} & State & 37 & 26,31 & 973,50 & & & \\
\hline & & & & & 270,500 & $-1,12$ &, 262 \\
\hline & Private & 18 & 31,47 & 566,50 & & & \\
\hline
\end{tabular}

3.1.4. Level Differences in Meeting the Expectations of Teachers According to School Levels by School Administrator

According to the results of the Kruskal-Wallis Test, no statistically significant difference was found in terms of the level of fulfillment of vocational expectations among school teachers working in primary, secondary, imam, or secondary schools, $\mathrm{X} 2(3, \mathrm{n}=55)=0.46, \mathrm{p}=0.93$.

Table 4. Level Differences in Meeting The Expectations of School Counselors According To Working Grades By School Administrator

\begin{tabular}{|c|c|c|c|c|c|c|}
\hline \multirow{2}{*}{ Points } & \multirow{2}{*}{ Groups } & \multirow{2}{*}{$\mathbf{N}$} & \multirow{2}{*}{$\begin{array}{c}\text { Mean } \\
\text { Ran }\end{array}$} & \multicolumn{3}{|c|}{ Kruskal-Wallis Test } \\
\hline & & & & $\begin{array}{c}\text { Chi- } \\
\text { Square }\end{array}$ & df & $\begin{array}{c}\text { Asymp. } \\
\text { Sig }\end{array}$ \\
\hline \multirow{8}{*}{$\begin{array}{l}\text { Working } \\
\text { Grade }\end{array}$} & Primary & 13 & 25,92 & \multirow{8}{*}{,458 } & \multirow{8}{*}{3} & \multirow{8}{*}{,928 } \\
\hline & School & & & & & \\
\hline & Secondary & 15 & 29,27 & & & \\
\hline & School & & & & & \\
\hline & İHSS & 1 & 22,50 & & & \\
\hline & High & 26 & \multirow[t]{3}{*}{28,52} & & & \\
\hline & School & & & & & \\
\hline & Total & 55 & & & & \\
\hline
\end{tabular}


3.1.5. The Differences Between the Levels of Meeting the Expectations of the Guidance Counselors by the School Administrators

According to the number of students in the schools where the guidance counselors work, the Kruskal-Wallis Test was applied on the data to look at the difference between the level of guidance counselors professional expectations. The results of this test revealed a significant difference between guidance counselors ( 1 st group less than 250 students, $n=2$, 2nd group-251 between 500 students, $n=18$, 3rd group -501 between 100 students, $n=23$, 4th group-1001 and higher student, $\mathrm{n}=12), \mathrm{X} 2(3, \mathrm{n}=55)=9.78, \mathrm{p}=0.02$. Accordingly, the median scores (Median $=$ 140) of the guidance counselors with the number of 1001 or above students were greater than those of the other 3 groups.

Table 5. The Differences Between the Levels of Meeting the Expectations of the Guidance Counselors by the School Administrators According to the Student Resources

\begin{tabular}{|c|c|c|c|c|c|c|}
\hline \multirow{2}{*}{ Points } & \multirow{2}{*}{ Groups } & \multirow{2}{*}{$\mathbf{N}$} & \multirow{2}{*}{$\begin{array}{c}\text { Mean } \\
\text { Ran }\end{array}$} & \multicolumn{3}{|c|}{ Kruskal-Wallis Test } \\
\hline & & & & $\begin{array}{c}\text { Chi- } \\
\text { Square }\end{array}$ & df & $\begin{array}{c}\text { Asymp. } \\
\text { Sig }\end{array}$ \\
\hline \multirow{5}{*}{$\begin{array}{l}\text { Number of } \\
\text { Students }\end{array}$} & $\begin{array}{ll}\text { Less } & \text { than } \\
250 & \end{array}$ & 2 & 14,00 & & & \\
\hline & $251-500$ & 18 & 25,31 & \multirow{4}{*}{9,783} & \multirow{4}{*}{3} & \multirow{4}{*}{, 021} \\
\hline & $501-1000$ & 23 & 24,98 & & & \\
\hline & $\begin{array}{l}\text { More than } \\
1001\end{array}$ & 12 & 40,17 & & & \\
\hline & Total & 55 & & & & \\
\hline
\end{tabular}

3.1.6. The Differences Between the Levels of Guidance Counselors Expectations by the School Administrators

Kruskal-Wallis Test was applied to understand the differences between the levels of schooling of occupational expectations by the number of guidance counselors in the school. According to the results of this test, there is a significant difference between the groups, X2 (3, $\mathrm{n}=55)=10.67, \mathrm{p}=0.01$. The median scores of the counselors (Median $=143$ ) who worked as 3 counselors in the school were found to be higher than the other 3 groups. 
Table 6. The Differences Between the Levels of Guidance Counselors Expectations by the School Administrators

\begin{tabular}{lcccccc}
\hline Points & Groups & N & $\begin{array}{c}\text { Mean } \\
\text { Ran }\end{array}$ & & \multicolumn{2}{c}{ Kruskal-Wallis Test } \\
\cline { 5 - 7 } & & & & $\begin{array}{c}\text { Chi- } \\
\text { Square }\end{array}$ & df & $\begin{array}{c}\text { Asymp. } \\
\text { Sig }\end{array}$ \\
\hline & 1 & 22 & 21,91 & & & \\
Number of & 2 & 17 & 25,88 & & &, 014 \\
School & 3 & 7 & 36,86 & 10,674 & 3 & \\
Counsellings & 4 and upper & 9 & 40,00 & & & \\
\hline
\end{tabular}

\subsubsection{Results of the Survey}

The percentages of the questionnaires and answers applied to 55 mentors are given below to determine the level of meeting the expectations of school counselors and psychological counselors working in schools.

Table 7. Table of the Survey Results

\section{Questions}

1 The school principal provides the necessary

space for the CounselingServices.

The space which the school principal has

2 provided for the CounselingServicesis under decent conditions to have a meeting.

The school principal keeps up with the

3 regulations and the legislative arrangements about the CounselingServices.

The school principal takes the opinion of the

4 Counseling Services whilst planning the upcoming applications and tasks.

The school principal provides the necessary

5 support for the tasks which are related to the Counseling Services such as the school visits, group tasks and seminars.

6 The school principal is actively in charge of the Counseling Services' commission.

The school principal provides the stationery

7 equipments and technological supports for the Counseling Services.

The school principal provides necessary

8 convenience(s) for the participations in inservice training and courses whilst supporting

\section{Sometimes}

Usually Always

$\begin{array}{lllll}0 & 2 & 3 & 10 & 40\end{array}$

$\begin{array}{lllll}(\% 0.0) & (\% 3.6) & (\% 5.5) & (\% 18.2) & (\% 72.7)\end{array}$

$\begin{array}{lllll}1 & 1 & 4 & 19 & 30\end{array}$

$\begin{array}{lllll}(\% 1.8) & (\% 1.8) & (\% 7.3) & (\% 34.5) & (\% 54.5)\end{array}$

$\begin{array}{lllll}3 & 5 & 9 & 14 & 24\end{array}$

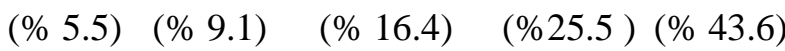

$\begin{array}{ccccc}2 & 4 & 13 & 13 & 23 \\ (\% 3.6) & (\% 7.3) & (\% 23.6) & (\% 23.6) & (\% 41.8)\end{array}$

$\begin{array}{lllll}1 & 3 & 2 & 10 & 39\end{array}$

$\begin{array}{lllll}(\% 1.8) & (\% 5.5) & (\% 3.6) & (\% 18.2) & (\% 70.9)\end{array}$

$\begin{array}{lllll}8 & 5 & 15 & 11 & 16\end{array}$

$\begin{array}{llllll}(\% 14.5) & (\% 9.1) & (\% 27.3) & (\% 20) & (\% 29.1)\end{array}$

$\begin{array}{ccccc}2 & 5 & 5 & 18 & 25 \\ (\% 3.6) & (\% 9.1) & (\% 9.1) & (\% 32.7) & (\% 45.5)\end{array}$

$\begin{array}{ccccc}1 & 1 & 8 & 15 & 30 \\ (\% 1.8) & (\% 1.8) & (\% 14.5) & (\% 27.3) & (\% 54.5)\end{array}$


the vocational developments within the Counseling Services.

9 The school principal believes in the importance of the Counseling Services.

$\begin{array}{ccccc}2 & 1 & 5 & 15 & 32 \\ (\% 3.6) & (\% 1.8) & (\% 9.1) & (\% 27.3) & (\% 58.2) \\ 2 & 2 & 7 & 15 & 29 \\ (\% 3.6) & (\% 3.6) & (\% 12.7) & (\% 27.3) & (\% 52.7)\end{array}$

The school principal reflects the care that it

$\mathbf{1 0}$ gives to the Counseling Services in the school environment.

The school principal cooperates with the

${ }_{11}$ psychological counselor and the school counselor in order to sturdily carry out the Counseling Services' tasks.

$\begin{array}{ccccc}0 & 3 & 7 & 16 & 29 \\ (\% 0.0) & (\% 5.5) & (\% 12.7) & (\% 29.1) & (\% 52.7) \\ & & & & \\ 1 & 6 & 8 & 13 & 27 \\ (\% 1.8) & (\% 10.9) & (\% 14.5) & (\% 23.6) & (\% 49.1) \\ 1 & 4 & 7 & 14 & 29 \\ (\% 1.8) & (\% 7.3) & (\% 12.7) & (\% 25.5) & (\% 52.7) \\ 4 & 3 & 8 & 12 & 28 \\ (\% 7.3) & (\% 5.5) & (\% 14.5) & (\% 21.8) & (\% 50.9) \\ & & & & \\ 1 & 1 & 8 & 12 & 33 \\ (\% 1.8) & (\% 1.8) & (\% 14.5) & (\% 21.8) & (\% 60) \\ & & & & \end{array}$

The school principal encourages the ${ }_{12}$ psychological counselor and the school counselor to cooperatively task with the Counseling and Research Center.

13 The school principal follows and keeps up with the problems at school.

The school principal gets the psychological

$\mathbf{1 4}$ counselor and the school counselor to feel themselves as a significant part of the school.

The school principal demands that the 15 psychological counselor and the school counselor act accordingly with their business ethics.

\subsection{Qualitative Research Results}

3.2.1. Guidance Counselors' Ideas on the Adequacy of Physical Working Conditions at School

In the answers of the counselors who participated in the research, the physical working conditions at the school; it has been observed that the guidance service evaluates the size and characteristics, equipment, location of the room, individual interviews and suitability for group work... A total of 10 counselors stated that the physical working conditions at the school were sufficient, while 5 counselors stated that the physical working conditions were insufficient. It has been observed that a large number of the guidance counselors qualify the physical conditions as sufficient, even if the two counselors work in the same room, one is leaving the room while the other is out of the room, the room is only suitable for the individual interview and the group work is done in other classes or areas, there is no telephone or students in the room.

\subsubsection{Some of the guidance counselors' opinions about physical conditions;}

R10: Physical conditions are moderately good; My room is on the ground floor where all the managers are on the floor. But the manager is not very close to their room. The school owner who passed away when the first entry of the door of the big picture of a desk. Room is not his old room. In the absence of disrespect to the table do not raise children. Let's feel comfortable because of the table when they first come to the room. Since he is very interested 
in kindergarten and secondary school, he is doing interviews on those floors. He is emptying the room while the student and parents are interviewing. In the room there is a round table outside my own work desk.

I do the student talks at the table. But the table stays high for the elementary school children. There is no suitable environment for group work. There is no printer. Because the computer was too old, it avoids me from using the table to no avail. As a computer, I bring my own laptop to work every day. Wardrobe is not enough. That's why I'm having trouble keeping files safe.

My working room was small but adequate for individual interviews. But there is not enough space for group activities. The number of courses and the taking of the guidance hours from the 10th and 11th grades increased the inadequacy of the guidance activities.

R12: About physical conditions; We are two people using the same room, because they don't have any other room they can give us right now. We are having trouble with the interviews as follows; I can't make calls while my other friend is interviewing. Sometimes an interview is held in both of us in the room. If you tell us what is the good part of this business, both of us are involved in any case and we are able to make difficult discussions more easily when we talk to children or parents. It may not be economical for two students to drop a student, but it can be good in terms of solving the problem quickly. Being in the same room isn't a problem because we're good. We take the time to have a private conversation, we are moving into a student room. Actually, we need a separate meeting room, but they didn't really give it up because there was no room at school.

R5: When the ideal physical conditions come to mind, the first computer and printer come to mind. Interviews and recording of these interviews are very important for the guidance service so you need to have your computer and printer. Besides, I think it should be a place that can be suitable for individual and group interviews in terms of heat, light, sound and silence.

3.2.2. Guidance Teachers' Opinions about Guidance and Psychological Counseling Services, Perspectives on Professional Ethics and Principles

When the overall evaluation was evaluated, a total of 12 guidance teachers' expressed their positive opinions about the professional ethics and principles of the managers and a guidance teacher expressed negative opinions.

Some of the participants who expressed their positive opinions about the professional ethics and principles of the managers stated that their managers did not interfere with the private works of the counseling service. The negative opinion of a chairman, the guidance service, is available on the website of the internal affairs, two people are approaching the problem of your friends about the guidance of the manager, you are wanted, we can approach one of your manager's problematic problem quickly, and if you have two friends, they express their opinion that your manager ignores his / her student.

The participants will be able to explain the characteristics of the ideal manager for professional ethics and principles;

They know the principles, do not interfere with internal operations, the presence of the school, supportive attitude, cooperate, reward employees, who understand the importance of the profession, do not give jobs that are not related to the field, who respect our profession and our opinion, support the education, consistent, just expressed as a form. 


\subsubsection{Some of the guidance counselors' opinions about physical conditions;}

R6: I do not have any problems with my manager about my professional ethics and principles in my school. But I've had a problem with a assistant manager. This is about full professional ethics. "- If you have made interviews, you have to let me know the contents of these interviews. in a discourse. About this I gave the answer to the headmaster of the school immediately before I opened my mouth. The content of the interviews made according to the regulation should not be notified, interviews were made in accordance with the principle of confidentiality, my school principal was warned by our deputy director and I did not have any problems with other managers.

R10: Since I am in private school, I have two administrators as primary school principal and general manager. I'm lucky about my primary school principal. He doesn't choke me out of unnecessary meetings and paperwork. I'm not on guard duty, I'm not even asked to enter the empty class. I'm just working on my field. This is because I present the reasons and planning of my work to my manager and I also share the outputs. For this reason, he points out that his perspective on psychological counseling and guidance changed.

They don't like when I suggest the principle of confidentiality sometimes, but they don't insist. In crisis situations, he can expect me to solve my problem immediately. Or, when there are students who need it for a longer period of time, there may be some reproaches about why the problem has not been solved.

R11: Our manager really supports us and he knows the guidance. When our new assistant manager arrived we had some trouble with him, he didn't know what we were doing, I think he had some prejudice, but his attitude changed as he knew the guidance. Sometimes there are new teachers, they do not know a lot of guidance service in that sense, we have a administration that stands behind the guidance service, and all the managers continue the attitude of the manager. In addition, our manager sometimes makes other things easier for the other administrators and teachers by saying "I think the words of the teachers are simple, let's make it easy".

R13: Our manager is in cooperation with us, I really feel it. When I have any problems, I realize that I have immediate support, and I like it very much and it is really good for our profession to approach this way. It is very important for us to respect us, to respect my profession, to respect my interview, and to say what you say about events in our field. He respects the privacy, says you keep the content in the event of an event if you think it is okay. This year we had 3 events in this way we called the child police, what is the content of my teacher do you say or do like this do not say. It feels really good to be with me and trust me.

R1: Unfortunately, our school administrators are unaware of guidance and counseling, so there is no perspective. Not only does someone follow them doing something... He doesn't even follow. We're not even on track. We have a control situation with our own internal mechanism, but we do not have any follow-up or understanding of the work done by the school administrators.

R1: I think a school head should know at least the basic principles of guidance and counseling, but not interfere in the internal functioning.

R3: I think that the ideal manager should not see the mentor who is idle because he / she doesn't have a lesson, but instead replace the vacant classes, and not see the unnecessary things. The task definition should not have such an understanding that the owner is not the owner of all the remaining tasks. The director should have an attitude that does not blame the 
teacher, who acts fairly, supports the teacher regardless of the parent. All teachers should take the opinion of teachers, give importance to the ideas of the teachers, all levels of fairness in all levels, who give importance to team work, failure to the entire team but the success of the whole team should follow a attitude that shares.

In addition, the guidance of the teacher about the student should not interfere with the way they prefer, but instead it should be in a supportive attitude.

R12: Let me tell you the characteristics of the ideal manager; for example, our manager is someone who challenges our boundaries but also someone who knows it is not right to keep watch. It gives duty on the seizure, but you cannot perform an authoritarian attitude, this task is also called sight, we are aware of our professional boundaries. There is a stern attitude that is expected towards the student. On the other hand, our director has his own personal problems and a strict attitude on many issues! I can say that we aren't forced about professional ethics, but if you just say what you wish, you can force us into everything that is not related to us.

R13: I don't know your point of view but in my opinion, wishing more than what I have would be a brattiness as I think that our principal is an ideal principal enough. I had situations in which I didn't have even this kind of a person...

3.2.3. School Counselors' Views on the Attitudes of School Administrators Towards to Their Personal and Professional Development

While 14 people stated that the attitude of the school management towards to their personal and professional development were positive, one person stated that it had been negative. The participants have stated the ideal school management attitude as; they should be supportive, contributing, not-blocking and participating in the means of the personal and professional development of the school counselors.

3.2.3.1. The school managers' attitude towards the personal development of the school counselors and the opinion of some of the school counselors

R1: In my opinion, a good manager should provide support to the education that will contribute to the development of the the school counselor both financially and spiritually. I think that any kind of support that is applied in this sense will become reflective.

R4: They support me to participate in trainings, seminars or in-service trainings. They agree that my well-being is for the benefit of the school.

R6: Some of the school managers support this idea whereas there are some who say "Is that another seminar? It will be boring and useless again and a waste of time, I wish it all just finished" and such opinions. They also think that when a school counselor is leaving, we are purposedly leaving them under a burden and I don't really like this situation.

R10: They should be supportive for the school counselors' education knowing that it is crucial in a sense that it could come in handy for their professional competence. 


\subsubsection{The Opinions of the School Counselors for the Conflicted Situations at Schools}

It has been observed that the school counselors judge the conflicted situations that take place at schools in a sense that the school managers are supposed to be supportive, neutral and democratic and that these opinions should be consulted during private meetings.

During the conflicts at school, the school counselor has 5 mentors who stated that they had a supportive attitude from the school management, while 5 counselors stated that they had a democratic and neutral attitude. There are 5 participants who state that their managers express their positive / negative opinions during private talks.

The participants have expressed the ideal school principal attitudes as those in which the principal listens to the opinions, tells the mistaken points during private meetings and becomes fair, solution-based and calm.

4.2.4.1. The attitudes of the school management and the opinions of an ideal principal in such cases

R5: It is generally like that; Conflicts are situations that are ought to be solved so therefore, first of all, they prefer to listen to everyone's opinion in such cases. For example, parents' opinions can be taken in those conflicted situations during teacher and parent meetings. In addition, the opinions of the teachers and us are taken. They try to find the solution to the problems with an aim of finding a solution. I can say that their attitude is positive in this sense.

R7: They talk to me later in case I am mistaken at any point, but their attitude is also in favor of the consulting services at most and my expectation is also in that way.

R8: In case of any conflict, our school administrators often give us the right to express ourselves and also trust us. During the conflicts, they consult our opinions and ask for our help.

R11: There might be conflicts at some points, but I have never had any problems with any of the parents up until now. Our principal never lets any parent scold the teachers or the school counselors in such conflicted situations. They try to find a solution, to find an opinion in between or just interfere, but they try to find a solution. Moreover, they also say that "If you let me, I will do the speech that is necessary, to them". He also does this speech without hurting any of the sides' feelings. He talks with us and also talks to the teacher when there is conflict with the teachers. Last year, I had a conflicted situation with one of my teacher friends. They talked to both of us and solved the problem without hurting any of us both. We can simply feel that neutrality. He tells to the opposing side: "This is their profession and they have to do this" while also telling me "This and this happened, but in such cases I am here, please consult me and do not quarrel".

R6: Our principal knows my attitude and behavior towards other teachers in conflicted situations. We have problems from time to time inside the school, or other teachers have them among themselves, and I think that they would care for my opinion because they know that I will provide them with solutions towards to these conflicted situations, Our principal knows my attitude and behavior towards other teachers in conflicted situations and I think that they would care for my opinion because they know that I will provide them with solutions towards to these conflicted situations. 
R8: Our reviews should be taken as a point of view that is different from the other opinions. Even though we are in minority as a PDR team, our exertions should be respected and our prestige should be protected as we make too much effort in that we serve to many people.

R9: My expectation from my managers is that they act fair between teachers during conflicted situations. The reaction that is given to the mistaken side should not depend on who is that person.

R10: I expect my school administrator to maintain their composure especially during the crisis situations. It is important to find the most appropriate solution to a situation without choosing a side when there is an incomprehension between the teacher and the guidance service.

4.2.5. School Counselors' Opinions about the School Managers' Asking for Their Opinion Whilst Making Decisions

Among the school counselors who participated in our research, it has been observed that the school managers usually do not prefer to take the opinions of the Counseling Services or rather merely take their opinions neutrally.

There are 7 people who state that the manager has received and applied the idea of the guidance service, while there is a person who states that the managers do not take the idea of guidance services in new decisions and practices about the school. While 4 of the participants state that their school management takes their ideas but applies what they know is best, 3 of the participants have made neutral commentaries.

4.2.5.1. Attitudes of the school managers towards the counseling services while asking for their opinions and some commentaries of how a great principal could be

R1: They do not take our opinions if the topic is something that concerns the school itself. They only ask for our opinions if there is something that we can do, but they don't if they can do it all by themselves.

R2: They ask for my opinion if I am there stating my opinions in several topics, but they will not always ask me for my opinion in every topic. They usually apply my opinion if I insist, even if they don't really like it.

R5: The ideas of the counseling are always taken in the new applications, asking them; "What are your opinions, what do you think?-", they take our opinions without any judgement, they listen to them and they care about them. We are also able to express our thoughts very comfortably.

R7: Our school principal is not asking us in all decisions, but asking us all that they don't know about the students, but he still takes our opinion anyway so we are still listened. I like it to be that way.

R8: We are partly resorted and partly forgotten. Whether they apply our suggestions or not, they still listen to our opinions anyway.

R10: They can sometimes manage the school classes' schedule (Like filling a day with full of English classes). They ask for my opinion in such circumstances. I present my ideas from a pedagogical point of view, but they still do what they think is right. 
R11: If there is a new application, if we are going to be in the business, that is, the board is a commission or something like that, we are often asked for our opinion. He says, "I can be an executive blind man, how do you see the school, give me information, you may know something and don't hide anything from me" to us. Not in means of an informant, but they want to know whether they're missing something. They sometimes do whatever is necessary when we say "This and this are missing, and we cannot have any wish from our teachers because we are not at their level. It would be better if you did it". We haven't had an application that we've been doing over the years but sometimes I said that this is what I'm going to do, in this way.

R12: I'm not really sure if they're really interested in our opinion. Applying to our view in the image refers to... They act as if they care about our ideas but still do what they consider is the best. They actually value our ideas when we think similar to them, therefore usually taking our opinion because of that.

But they give us information about almost everything, they guide us about every topic whether it is related to us or not. Due to that interesting type of personality, it cannot be described with words but instead, it should be witnessed with eyes. I can neither get angry or not get angry in this different type of person...

R15: When a decision is taken on new applications, it usually takes a meeting, takes a few teachers, receives guidance, asks everyone's opinion and meets a common decision. The decision is applied if it is decent but if disagreed, it isn't.

R1: The opinion of the counselor is absolutely important in the decisions and new practices concerning the functioning of the school. I think that at least 1 counselor should be consulted.

R6: I think the school manager should include the guidance counselor in these practices in new applications. I wish the application was not in this way though, but unfortunately...

R8: I think it would certainly be beneficial to consult a guidance service in the name of providing a different view and in the name of the power of our scans and data. If it were me, I would definitely take advantage of the PDR unit's field dominance and foresight.

\section{Discussion and Conclusion}

\subsection{Discussions on the Guidance of Teachers on the Adequacy of Physical Working Conditions at School}

The counselors who participated in the research were asked questions about the adequacy of the physical working conditions in their schools.

Participants were evaluated the size and characteristics of the guidance service, the equipment, the location of the room, individual interviews and the suitability of the group work. A total of 10 mentors stated that the physical working conditions at the school were sufficient, while 5 mentors stated that the physical working conditions were insufficient.

In the survey conducted in the quantitative part of the study;

$90.9 \%$ of the guidance counselors gave a positive answer for the school administrator who provides the necessary space for psychological counseling and guidance. $89 \%$ of the counselors gave a positive answer to the question of whether the school administrator provided the facilities for psychological counseling and guidance. 
It has been observed that a large number of the guidance counselors qualify the physical conditions as sufficient, even if the two mentors work in the same room, one is leaving the room while the other is out of the room, the room is only suitable for the individual interview and the group work is done in other classes or areas, there is no telephone or students in the room. While the guidance teachers met the needs of the guidance service, it was observed that they were not demanding in fulfilling the conditions required for the performance of the profession, and they went to adapt to the conditions of the school.

These data indicate that in the case of Bicak (2018), the guidance teachers obtained in their researches have improved in school physical conditions and the approaches of the administrators in this direction, their wishes regarding physical needs are taken into consideration and their tendencies are positive and constructive. It supports each other with the research data which states that some demands cannot be met due to limited opportunities of school administrators.

One of the researches on this subject belongs to Karaküçük (2010). In his research, Kucuk revealed that counselors had moderately favorable room conditions, and that this had nothing to do with the disadvantage of being in government offices.

Trust (2009); the studies of Hamamci Murat and Coban, (2004) are among the studies that the managers found to be inadequate in their equipment and attitude about PDR field.

\subsection{Discussions on the Views of the Guidance Counselors on the Guidance and Psychological Counseling Service of School Administrators, Their Perspectives on Professional Ethics and Principles}

The counselors who participated in the research were asked questions about the opinions of the school administrators on the guidance and psychological counseling service, their perspective on professional ethics and principles.

A total of 12 counselors reported positive opinions about the managers' professional ethics and principles, while 1 counselor expressed negative opinions.

Two guidance counselors defined their managers as regulations-oriented and did not define them as positive or negative.

In the survey conducted in the quantitative part of the study;

$81.8 \%$ of the guidance counselors gave positive answers to the behavior of the school counselor.

Not only in the survey but also in the interviews is it stated that, although it is thought that the school management usually goes against the rules of the business ethics of the Counseling Services, they usually use the Counseling Services as an idea source which is ought to make things faster for them. Moreover, it is also observed that the school management is more likely to interfere with the works of the School Counseling. Some school counselors have stated their opinions in this aspect that their business ethics are neglected.

This shows that the general attitudes of school administrators are positive in terms of their professional ethics and principles, and that the guidance teachers focus on the general attitudes of their principals by ignoring the negativity mentioned above. 
These data coincide with the findings of Ozturk (2018) that there are few guidance counselors who generally see school administrators as egalitarian and fair leaders in democratic behaviors, and that they do not find their behavior democratic.

\subsection{Discussions on the Views of School Administrators on Personal and Professional Development of Counselors}

The counselors who participated in the research were asked about the attitudes of school administrators towards their personal and professional development. While 14 of the counselors gave a positive opinion, one person reported a negative opinion. In the survey conducted in the quantitative part of the study; $81.8 \%$ of the participants responded positively to the matter of supporting the professional development of the school counselors and counselors, providing the necessary ease of participation in the in-service training and courses.

This situation shows that the questionnaire and the interviewers give similar results, and that the school administrators exhibit a high level of support for the personal and professional development of the mentors.

\subsection{Discussions on the Views of the Guidance Counselors on the Attitudes of School Administrators in the Conflict Situations in School}

The counselors who participated in the research were asked about their opinions about the attitude of the school administrators in the conflict situations. While 9 mentor teachers participated in the interview stated that the guidance counselor displayed a supportive attitude in case of conflict in school, 5 mentor teachers stated that they exhibited a neutral attitude in the case of discussion. 5 mentors stated that their managers expressed their positive / negative opinions in one-to-one interviews.

In the survey conducted in the quantitative part of the study;

$83.7 \%$ of the participants gave a positive answer to the matter that the school administrator gave the necessary support to the psychological counseling and guidance service in case of problems with the parents..

$65.5 \%$ of the participants gave a positive answer to the matter that the school administrator gives the necessary support to the psychological counseling and guidance service in case of problems with the administration or other teachers.

This situation shows that, in case of conflict with parents, the school administrators have an attitude that supports the guidance counselors, and that they show a neutral and conciliatory attitude between the guidance service and the teachers in the school conflicts.

\subsection{Discussions of the Counselors Views on the Attitudes of School Administrators to Apply to the Guidance Service for New Decisions and Practices in the School}

The counselors who participated in the research were asked about their attitudes towards the school administrators to apply to the opinion of the guidance service in the new decisions and applications about the school. While there is a mentor who states that the managers do not get the idea of guidance services in the new decisions and practices about the school, there are 7 people who stated that the manager received and applied the idea of the guidance service. 4 of 
our participant managers get ideas, but do not know what to do, 3 participants were neutral in this regard. In the survey that was made in the investigation's quantitative section; The $65,4 \%$ of the participants have responsed positively to the article of "The school principal takes the opinion of the Counseling Services whilst planning the upcoming applications and tasks" in the survey.

When the responses are attentively investigated, it is likely to be demonstrated that the school management counterparts take the opinions of the Counseling Services in an high rate but also, these opinions are usually not reflected to the executions that are applied.

\subsection{The Difficulties that Take Place in Counseling}

As it had been pointed out in the previous sections whilst interpreting the development of the Counseling Services profession, the PDR services and studies have started much earlier in our country than they had started in a majority of the European countries. Despite this earlier progress; the fact that it doesn't contain a specific standard, that the definition of its aim is uncertain and that its applications change from person to person, it could be stated that the PDR is a profession which still has an identity crisis. The main reasons of this circumstance could be summed up with these implications:

The Counseling Services at the schools had been started based on the American model whilst the lack of necessary preliminary preparations and the preliminary educations of the school management staff and the instructors. This situation still proceeds and the school counselors usually devoid of the support that they need.

Yet another problem with having the American model PDR services as a sample is that these two countries aboundingly differ in means of culture and education system.

Raising the each individual of the Turkish Nation sturdily under balance, in means of physical and spiritual aspects is among the basic aims of our education system. Furthermore, the idea of raising individuals who respect humanity \& human rights, have a broad vision of the world, contain creativity and apply themselves is also among the basic aims of the Ministry of National Education. However, deciding the routes or aims and changing the centrist understanding of education and convincing the public to accept these alterations cannot be applied simultaneously. This circumstance often leads the school counselors to usually side with the students and act as a separate unit from the school management members and the instructors and therefore, they are not only critisized but also even led to conflicts with their counterparts.

One another reason is that the school counselor doesn't have a specific place in the hierarchical classification. If observed throughout the institutions, examples in which the school counselor directly cooperates with the school principal could be witnessed whereas there are situations in which the school counselors are ranked below the school management counterparts, making the school counselors ranked as same as the school teachers. In fact, the school counselor is also required to be out of the crew at several situations as well as being a part of the school crew. These uncertainties such as of the students' demands often take place and often, gets the school counselors in solitariness.

Giving different captions to the psychological counselors \& the school counselors, and the fact that people who graduate from different graduations are all falling under PDR are among the other difficulties that this profession faces. 
Yet another problem that takes place at schools is the lack of necessary places, tools, agents and hardwares for the PDR services to proceed. It has been observed that the school counselors are attempting to keep their schedule up with a decent level under the circumstances of the school rather than to strive with the necessities and needs of the students. This situation therefore leads the Counseling Services to give more importance to several factors $\&$ fields and hence ignore the other factors and fields. These recent investigations and observations demonstrate that the Counseling Services are more likely to serve with an aim of professional guidance and crisis management.

It is observed that the psychological counselors' and the school counselors' getting tasked in the paperworks, managemental works or social activity organizations' works as well as being on a guard duty, becomes contradictory to their business ethics.

The tremendous count of students at schools' being superabundant for the Counseling Services to serve, the frequent changes in the system, the period and the necessities of the students and the fact that the school counselors cannot keep up with the rapidness of this continuum, reserves an incontrovertible place within the problems that are related to PDR.

There has been a process of standardization as of the 2007-2008 Education Term in means of PDR educational programs. However, this regulation that was applied by YÖK (The Council of Higher Education) has been made without any cooperation with the MEB (The Ministry of National Education) and thus, the perceptible differences among these programs still proceed.

Under the aspect of the legislative regulations, the lack of profession laws and the trade association, the emergence of the Counseling Services and Tutoring Services to the same moderation, the frequent changes in the regulations and the arbitary changes that are made by people who are not concerned with the opposing profession against the business ethics are the adverse circumstances with the regard of Counseling Services.

Despite the fact that its space of service more limited, the care and interest that is given to the tutoring is far more than that of Counseling Services and this could be counted as one of the adverse circumstances.

\subsection{Suggestions}

Benefiting from these solutions which were obtained in this section of the research, there has been several suggestions which aim to increase the level for meeting the expectations of the psychological consultants and the school counselors who are working at the school.

1. It is thought that the teachers' and the deputy managers' receiving of education about the content and the importance of the consulting services could decrease the clashes that take place at schools and moreover become benefiting for the students.

2. In order for the consulting services at the schools to proceed sturdily, the working conditions of the consulting services must be improved and a standardization for the consulting services should be auspicated.

3. Along with the fact that the supportive act of school principals towards to the school counselors' personal and occupational development is a decent progress, the count and the qualifications of the courses and tutelages for the school counselors, from whose positive atmosphere they could gain favor, should to be increased. 
4. The "School counselors are ought to be focused on the duty of watch" inscription, which could be found in the Regulations of Consulting Services that was published at November 10th, 2017 has taken too much reaction due to its failing to comply with the professional ethics and principles of the Counseling Services and therefore, it has been witnessed to merely stand on paper. It should be noted and not forgotten that the school counselor won't have an act of disciplining and this article should be removed from the regulations. Consulting Services at the schools are not merely services which aim to solve conflicts and to guide scholars in their professions. It is vital that the other extents of the Consulting Services should not be forgotten.

5. In the Regulations of the Consulting Services and Tutoring, the responsibilities of the principal, the deputy manager and the classroom teachers for the Consulting Services are clearly indicated. These duties and responsibilities must be known and applied by all the instructors.

6. This research merely involves the school counselors at schools in the Sariyer discirt which proceed their educations. This research could be expanded to school counselors who work countrywide.

7. There is an inscription in the Regulations of Consulting Services in which the "The School Counselors' Preference Consultancy could be tasked with missions which will take place during the holiday/break terms as the tasks of course and class selections, with its mergence to the process of student diagnosis" inscription is inscribed. The fact that these selection periods' dates are not specified, that these dates also coincide with Summer and that the school counselors that are tasked for during that timeline are underpaid results with the school counselors' rejection of participating in such tasks. Regulations in the date and the salary for this situation are seemingly required.

8. It has been observed that in schools where more than one school counselor are tasked that the school counselors get support from each other, that they don't feel alone and that these school counselors' level of the meet for the expectations of their profession is higher. It should be made sure that the vacant norms of the school counselors should be lapsed.

It shouldn't be forgotten that the psychological counselors' and school counselors' roles at schools should be made more active and practical as well as the fact that they should be provided with the conditions through which they could carry out their responsibilities and necessities for their tasks and that this is one of the most important factors for the Ministry of National Education's basic aims to educate students as projected. 


\section{References}

Aktepe, I. (2008). Rehber ogretmenlerin yonetici ve ogretmenlerden mesleki beklentileri (Unpublished master thesis). Yeditepe University Institute of Social Sciences, Istanbul, Turkey.

Ay, M. E. (2000). Egitim ogretim acisindan ilahiyat fakultelerinde rehberlik. Bursa: U.U. Publishing.

Aytac, T. (2000). Okul merkezli yonetim. Ankara: Nobel Publishing.

Bicak, D. K. (2018). Resmi okullarda gorev yapan rehber ogretmenlerin okul yoneticilerinden ve ogretmenlerden beklentileri (Unpublished master thesis). Gazi University Institute of Educational Sciecnes, Ankara, Turkey.

Gazioglu, E. O., \& Sengul, M. (Ed.) (2008). Ogretmen ve ogretmen adaylari icin rehberlik. Ankara: Pegem Academy Publishing.

Glanz, E. C. (1974). Guidance: Foundations, principles and techniques. Boston: Mas.Allynand Bacon Co.

Guven, M. (2009) Milli egitim bakanligi mufettislerinin okul rehberlik hizmetleri ve denetimiyle ilgili gorusleri. Uluslararast Sosyal Arastirmalar Dergisi, 2(9), 171 - 179.

Hamamci, Z., Murat, M., \& Coban, A. (2004, July). Gaziantep'teki okullarda calisan psikolojik danismanlarin mesleki sorunlarinin incelenmesi. Paper presented at $13^{\text {th }}$ National Educational Sciences Council, Inonu University Faculty of Education, Malatya.

Karakucuk, S. (2010). Okul rehberlik servislerinin fiziksel/mekansal kosullarinin incelenmesi (rehber ogretmenlerin mekansal algilari baglaminda). Sosyal Bilimler Enstitusu Dergisi, 28(1), 421-440.

Kaya, A., \& Asim, C. (2003). Okul psikolojik danisma ve rehberlik programlarinin gelistirilmesi, psikolojik danisma ve rehberlik. Ankara: Pegem Publishing.

Kuzgun, Y. (2000). Rehberlik ve psikolojik danisma. Ankara: OSYM Publications.

Ozoglu, S. C. (1982). Egitimde rehberlik ve psikolojik danisma. Izmir: Ege University Press.

Ozoglu, S. C. (1997). Egitimde rehberlik ve psikolojik danisma. Ankara: Ankara University Press.

Ozturk, D. N. (2018). Okul yoneticilerinin okul rehberlik hizmetlerine ve rehber ogretmenlere yonelik tutum ve davranislarinin rehber ogretmen gorusleri acisindan incelenmesi (Unpublished master thesis). Karadeniz Teknik University Institute of Educational Sciences, Trabzon, Turkey.

Sirin, A. (2004). Psikolojik danisma, egitimde ucuncu boyut psikolojik danisma ve rehberlik. Istanbul: Birsen Publication.

Tan, H. (2000). Psikolojik danisma ve rehberlik teori ve uygulama. Ankara: M.E.B. Publication.

Terzi, I. S. (2005). Okul psikolojik danisma ve rehberlik programlarinin gelistirilmesi, psikolojik danisma ve rehberlik. Ankara: Ani Publishing.

Turkoglu, A. (1997). 99 soruda egitim bilimine giris. Izmir: Memleket Gazete ve Press.

Yildirim, A., \& Simsek, H. (2016). Sosyal bilimlerde nitel arastirma yontemleri. Ankara: Seckin Publishing. 
Yilmaz, H., \& Ure, O. (2002). Rehberlik. Konya: Cizgi Bookstore.

\section{Biodata of the Corresponding Author}

Meltem Ceylan works as Assistant Director of Istanbul Sariyer Guidance and Research Center. She is also a master student in the Department of Education Management and Supervision at Istanbul Aydin University, Istanbul. 